\title{
Physiological vitality of Norway spruce (Picea abies L.) stands along an altitudinal gradient in Tatra National Park
}

\author{
Gabriela Jamnická ${ }^{1}$, Alena Konôpková ${ }^{* *}$, Peter Fleischer jr. ${ }^{1,2}$, Daniel Kurjak ${ }^{2}$, \\ Peter Petrík ${ }^{2}$, Anja Petek ${ }^{2}$, Hana Húdoková ${ }^{1,3}$, Peter Fleischer ${ }^{2}$, Zuzana Homolová ${ }^{4}$, \\ Marek Ježík ${ }^{1}$, Lubica Ditmarová ${ }^{1}$ \\ ${ }^{1}$ Institute of Forest Ecology, Slovak Academy of Sciences, L. Štúra 2, SK-960 01 Zvolen, Slovak Republic \\ ${ }^{2}$ Technical University in Zvolen, Faculty of Forestry, T. G. Masaryka 24, SK-960 01 Zvolen, Slovak Republic \\ ${ }^{3}$ Technical University in Zvolen, Faculty of Ecology and Environmental Sciences, T. G. Masaryka 24, \\ SK-96001 Zvolen, Slovak Republic \\ ${ }^{4}$ Research station of Tatra National Park, SK-05960 Tatranská Lomnica, Slovak Republic
}

\begin{abstract}
Nowadays, a large area of Norway spruce forest stands in Europe is disturbed by windstorm and, subsequently, bark beetle outbreaks. We investigated the state of three disturbed spruce stands along an altitudinal gradient in Tatra National Park (Slovakia) through various physiological processes. Tree-growth characteristics, the mineral nutrition in the needles, and photosynthetic efficiency were assessed. Two techniques of chlorophyll $a$ fluorescence and analyses of assimilatory pigments were used to detect the changes in photosynthesis functioning. Also, the heat sensitivity of photosystem II was tested. Our results showed that these stands are located in nutrient-poor environments. We recorded similar contents of nitrogen, phosphorus, potassium, sodium, zinc, and iron in all stands. Down the vertical transect, the contents of calcium, magnesium, and manganese significantly decreased and the non-essential aluminium increased. Based on stem circumference measurements, water deficit occurred during the vegetation season in all stands, but with the smallest magnitude highest $\mathrm{U}-$ stand. We found some photosynthetic constraints: slightly lower chlorophyll contents in all stands were recorded; however, seasonal dynamics with increasing chlorophyll concentration in the highest U-stand were observed. Moreover, the photochemistry of the lowest D-stand was the most negatively influenced by simulated heat, as the photosynthetic performance index, and the density of the active reactions centres significantly decreased and the values of the $\mathrm{K}$-step and basal fluorescence increased. Therefore, we can conclude the different levels of physiological vitality in these naturally damaged spruce stands, with the best physiological performance of the trees in the highest stand.
\end{abstract}

Key words: spruce stand disturbances; heat stress; mineral nutrition; chlorophyll a fluorescence; stem circumference

Editor: Zuzana Sitková

\section{Introduction}

In the context of climate and environmental change, the growth and vitality of Norway spruce, a dominant component of European mountains, may be called into question. Indeed, due to the increased scale of weather extremes and other damaging agents, the health status of spruce stands has considerably worsened in the whole Central European region (Uniyal \& Uniyal 2009; Allen et al. 2010; Lindner et al. 2014). Climate-induced physiological stress and interactions with other processes, such as natural disturbances and insect pest gradations, can lead to the mortality of whole spruce populations and can create a major change in forest communities.

Windstorms play a crucial role as primary agents in the Atlantic and Continental temperate zone of Europe (Spiecker 2003; Schütz et al. 2006; Zúbrik et al. 2013). Windstorms and bark beetles (Ips typographus and Pityogenes chalcographus) have been the most damaging agents for spruce stands in Slovakia within the last two decades. The decline of spruce stands has increased, particularly after windthrows Alžbeta (on 19 November 2004) and Žofia (on 15 May 2014) (Koreň 2005; Fleischer \& Homolová 2011; Kunca et al. 2019). The 
co-occurrence of increasing drought periods additionally seriously weakens spruce trees, hence their shallow roots and relatively high sensitivity to water deficits (Jyske et al. 2014; Tužinský et al. 2017). Drought-weakened trees are not able to produce enough resin or protective substances to withstand the pressure of bark beetles (Hlásny et al. 2014; Vakula et al. 2015; Kunca et al. 2019). Moreover, there an increasing upward shift in altitudinal outbreaks of bark beetles has been observed (Schwarz \& Moravčík 2009).

The physiological processes of such weakened trees are negatively impacted. The ability to conduct water effectively is reduced, and every change in the transpiration stream also influences the transport of nutrients to the foliage (Ditmarová et al. 2007a; Bonan \& Van Cleve 1992). The disintegration of adult spruce stands is also promoted by serious nutrient disturbances (Šrámek et al. 2008) and low contents of basic cations (nutrition factors), primarily potassium and partially calcium. The low content of potassium indicates the insufficiency of the water regime in spruce trees (Jokela et al. 1998; Ditmarová et al. 2007a). The nutrient concentrations in conifer needles strongly influence their biochemical capacity for photosynthesis and growth, particularly the impact of $\mathrm{N}$ and $\mathrm{P}$ on changes in the structure and function of the photosynthetic apparatus (Fredeen et al. 1990; Chen et al. 2013). Also, the interaction of Al, Mn, and other risk elements may mirror the conditions in the air and soil. Needle biomass productivity may decrease, and if the defoliation is not temporary, it can bring about strong negative effects in photosynthetic efficiency and its related processes.

Chlorophyll $a(C h l a)$ and $b(C h l b)$ represent important pigments for the primary reaction of photosynthesis (Baker 2008). Chl $a$ and Chl $b$ absorb sunlight at different wavelengths, leading to the assumption that the total leaf chlorophyll content $(\mathrm{Chl} a+b)$ and the allocated ratio $(C h l a / b)$ directly influence the photosynthetic capacity of plants. Consistently, the anti-oxidative mechanism of spruce needles also depends on the concentration of carotenoids. Low values of the $\mathrm{Chl} a / b$ and $\mathrm{Chl} / \mathrm{Car}$ ratios manifest a weakened photo-protective function of the photosynthetic apparatus. However, it is still unsure how leaf $C h l$ content varies among plant species, plant functional groups, and communities in natural forests, especially on a larger scale (Croft et al. 2017; Ying et al. 2018).

Recently, slow and fast chlorophyll $a$ fluorescence (Chl a fluorescence) kinetics and the JIP test (Strasser et al. 2000) have become popular methods for the rapid screening of stress effects on the physiological processes of trees. In comparison to the basic fluorescence parameters, these measurements provide additional information on the photochemistry of photosystem II (PSII) and the photosynthetic electron transport chain. Chl a fluorescence techniques can also provide new insights into the fundamental process of photosynthesis for forestry purposes (Kalaji et al. 2014; Bussotti et al. 2020).

In this study, we investigated the state of naturally disturbed spruce forest stands along the vertical transect of Lomnicky peak in Tatra Mountains, Slovakia, by analyzing their physiological traits. Using the data from three forest stands affected by a windstorm in 2004 and subsequently damaged by spruce bark beetles, we identified the tree-growth characteristics and the mineral nutrition in the needles, as well as explored variations in the photosynthetic efficiency through quantitative and qualitative analyses of photosynthetic pigments and chlorophyll $a$ fluorescence. The main objectives of this study were: (1) To evaluate the changes in the stem circumference of spruce stands along the transect; (2) to compare the state of the mineral nutrition and contents and ratios of assimilatory pigments in the needles; (3) to test the PSII performance and thermostability using two fluorescence techniques, namely slow kinetics-rapid light curves (RLCs)-and fast kinetics of Chl a fluorescence; and (4) to investigate how the assimilatory pigments and Chl a fluorescence vary during the season in spruce forests of different vitality levels.

\section{Material and methods}

\subsection{Transect description}

The study sites are located along vertical transect on the south-east slope below the Lomnicky peak in Tatra Mts. (inner western part of the Carpathian Mountains), which arenaturallycoveredby Norwaysprucestands(Fig.1). The lowest site (D) is located at 1,100 ma.s.l., the middle(M) at $1,300 \mathrm{~m}$ a.s.l., and the highest (U) at 1,500 $\mathrm{m}$ a.s.l.; the basic characteristics of individual sites are displayed in Table 1.

Due to occasional downslope winds, the age and structure of the forest differ in lower and higher altitudes. Mostly old growth pure spruce stands (over 120 years) dominate above 1,300 $\mathrm{m}$ and successional forests with European larch and Scots pine admixtures at lower elevations. Shallow stony podzols are typical at higher altitudes on steep slopes and deeper dystric cambisols in mountain foothills formed by moraines. According to the closest meteorological stations, the annual average air temperature ranges between $5.3^{\circ} \mathrm{C}$ (Tatranska Lomnica, $830 \mathrm{~m}$ a.s.l.) and $1.6^{\circ} \mathrm{C}$ (Skalnate Pleso, $1,360 \mathrm{~m}$ a.s.l.) and the average yearly precipitation from 800 to $1,200 \mathrm{~mm}$.

The health status of the forests of the Tatra Mountains has been deteriorating for decades. In the past, the key factor was distance and ozone pollution. Recently, strong winds and especially bark beetle attacks stimulated by warmer and drier conditions have caused an unprecedented decline in health. 


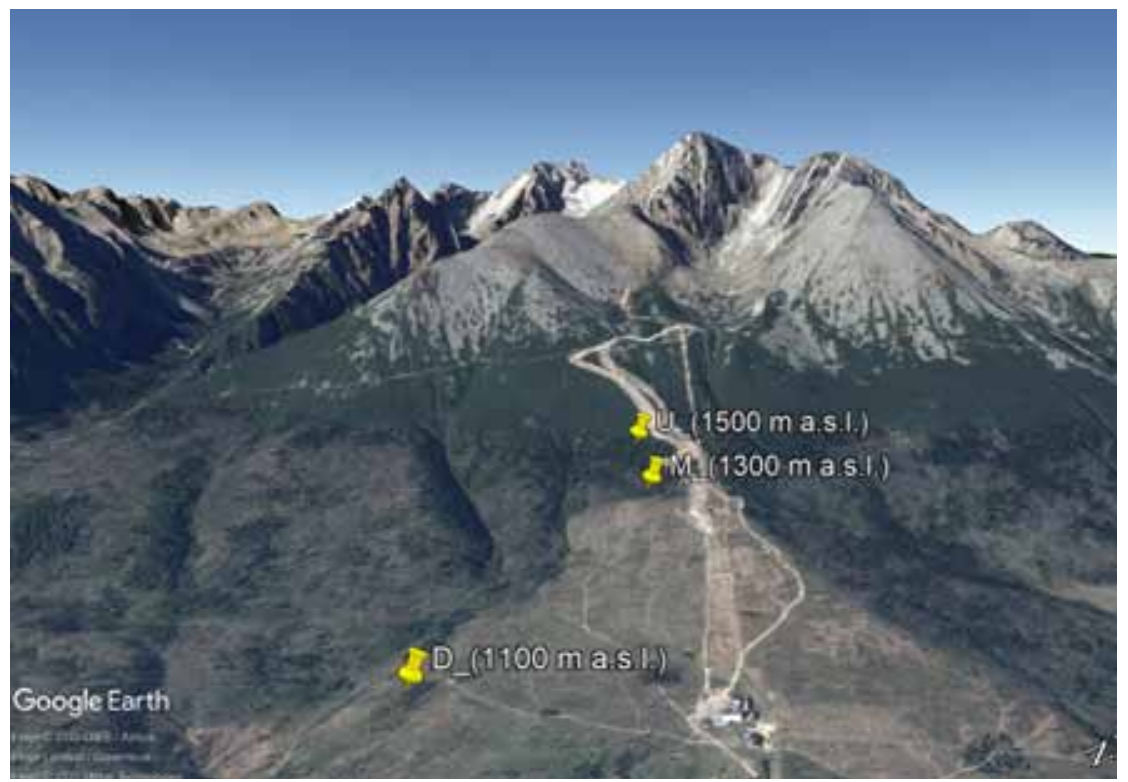

Fig. 1. Forest spruce stands along the vertical transect below the Lomnicky peak in Tatra Mountains, Slovakia.

Table 1. Description of the studied sites - three forest spruce stands along the vertical transect: the D-stand (lowest), the Mstand (middle) and the U-stand (upper).

\begin{tabular}{|c|c|c|c|c|c|c|c|c|c|}
\hline $\begin{array}{l}\text { Spruce } \\
\text { stand }\end{array}$ & $\begin{array}{l}\text { Altitude } \\
\text { [m a.s.l.] }\end{array}$ & Exp. & $\begin{array}{l}\text { Slope } \\
\text { (deg.) }\end{array}$ & Surface/vegetation & Soil & $\begin{array}{c}\text { Age } \\
\text { [years] }\end{array}$ & Stocking & $\begin{array}{r}\text { Tree species composition } \\
{[\%]}\end{array}$ & Defoliation \\
\hline$\overline{\mathrm{D}}$ & 1,100 & SE & 10 & stony surface & Dystric Cambisol & 100 & 0.8 & spruce 65 pine 15 larch 25 & 43 \\
\hline M & 1,300 & SE & 35 & boulder surface & Dystric Cambisol & 165 & 0.4 & spruce 70 larch 30 & 42 \\
\hline $\mathrm{U}$ & 1,500 & SE & 35 & $\begin{array}{l}\text { boulder surface, high occurrence of } \\
\text { mosses and Vaccinium myrtillus }\end{array}$ & Podzol & 165 & 0.4 & $\begin{array}{l}\text { spruce } 70 \text { larch } 25 \\
\text { rowan } 5\end{array}$ & 33 \\
\hline
\end{tabular}

\subsection{Meteorological data}

Environmental variables (air temperature and humidity, solar radiation in $2 \mathrm{~m}$ above ground) were recorded every 20 minutes by automatic meteorological stations (Minikin, EMS Brno, CZ) on the D and U sites and precipitation by automatic ombrometer (EMS Brno, CZ) on the D site. Gypsum blocks (EMS Brno, CZ) were installed on all study plots in $15 \mathrm{~cm}$ depth to measure soil water potential (SWP) once an hour.

\subsection{Stem circumference measurements}

To describe tree water status as an indicator of tree vitality, we measured variations in stem circumference. Stem changes were recorded with high-resolution automatic band dendrometers (model DRL 26, EMS Brno, CZ, accuracy of $\pm 1 \mu \mathrm{m}$ ) that were installed on 30 sample trees (10 trees per plot). The dendrometers were installed in April 2017. On the U plot the tree no. 31 was attacked by bark beetle. Visible symptoms of dieback (strong discoloration and defoliation) occurred in mid-August 2017. Despite this fact dendrometer recording continued in order to identify dead wood response to environmental factors. To ensure the close contact of dendrometer bands with tree stems and to reduce the influence of bark swelling and shrinkage, the outermost part of the bark was carefully removed before the installation of the dendrometers. For the purpose of this study, only the period from the 12th of April to the 6th of September 2018 was taken into account. The circumference measurements were recorded in 20-min intervals, which allowed to extract water deficit $(\Delta \mathrm{W})$ as a proxy for tree water status. Water deficit was calculated from growth-detrended dendrometer records according to Ehrenberger et al. (2012).

\subsection{Physiological data collection}

Physiological measurements and sampling for pigment analysis were carried out on 10 individual trees per plot at the beginning of June and at the end of August 2018. The needles for the mineral nutrition analyses were collected at the end of August, according to the general recommendation that foliage should be sampled for mineral diagnostic purposes in the late summer, autumn, or winter, thus not in the period of intensive growth. Such sampling reduces the influence of stored carbohydrates and improves the nutrient status after growth has ceased (Linder 1995).

Sampling was performed with respect to minimizing the variability based on the age of the needles and their position within the crown. The needles of 1-year-old shoots were collected from sun-exposed branches from 
the upper part of the crown by professional climbers. The samples were immediately packed into plastic bags and put into a transportable refrigerator cooled to $15^{\circ} \mathrm{C}$ to avoid dehydration or overheating during the transport to the laboratory. The measuring was done next day; hence the parameters of chl $a$ fluorescence are relatively stable and can be reliably measured up to two days after sampling without significant changes in PSII photochemistry (Húdoková et al. 2017).

\subsubsection{Analysis of the mineral nutrition in spruce needles}

The contents of the individual mineral nutrients in the needles were determined from dry mass obtained by drying ground samples at $60-70{ }^{\circ} \mathrm{C}$ for $48-72$ hours in an oven. Dried needle samples could be stored for longer period without deterioration occurring. Nitrogen $(\mathrm{N})$ elemental analysis, which uses a thermal conductivity detector (the EA-TCD method), was used. The method of atomic emission spectrometry with inductively coupled plasma (AES-ICP) was used to determine the amounts of phosphorus $(\mathrm{P})$, calcium $(\mathrm{Ca})$, magnesium $(\mathrm{Mg})$, potassium $(\mathrm{K})$, sodium $(\mathrm{Na})$, iron $(\mathrm{Fe})$, manganese $(\mathrm{Mn})$, aluminum (Al), boron (B), zinc $(\mathrm{Zn})$, and copper $(\mathrm{Cu})$. The analyses were performed in accredited the Central Forestry Laboratory of National Forest Centre, Zvolen, Slovakia.

\subsubsection{Quantitative analysis of the pigments}

A homogenized sample mixture $(1 \mathrm{~g})$ of spruce needles from each of the 10 individual trees per studied site were analyzed as $80 \%$ acetone extracts. The chlorophyll contents (Chl $a, C h l b$, and Chl $a+b)$ and total carotenoids $(C a r x+c)$ were determined by spectrophotometry (Cintra, GBS Australia) at 470, 646, and $663 \mathrm{~nm}$ and were calculated according to Lichtenthaler (1987). The pigment contents were related to the dry mass unit (mg. $\left.\mathrm{g}^{-1}\right)$.

\subsubsection{Fast kinetics of chlorophyll a fluorescence}

The needles were dark-adapted for 30 min using the leaf clips, and then chlorophyll $a$ fluorescence was excited by a saturation pulse with an intensity of $3,500 \mu \mathrm{mol} \mathrm{m}{ }^{-2} \cdot \mathrm{s}^{-1}$ for $1 \mathrm{~s}$. A plant efficiency analyzer, namely, the Handy PEA (Hansatech Ltd., UK), was used for the OJIP transient measurements, which were analyzed based on the JIP test (Biolyzer 5 software, Laboratory of Bioenergetics, University of Geneva, Switzerland). We determined the basic fluorescence parameters: The basal fluorescence $\left(F_{0}\right)$, measured $50 \mu$ s after illumination and the maximal quantum yield of PSII $F_{\mathrm{v}} / F_{\mathrm{m}}$, calculated as the ratio between the variable fluorescence $\left(F_{\mathrm{v}}=F_{\mathrm{m}}-F_{0}\right)$ and the maximal fluorescence $\left(F_{\mathrm{m}}\right)$. Moreover, the photosynthetic performance index on an absorption basis $(P I)$, the density of active reaction centers $(R C / A B S)$, and the value of K-step ( $W k)$ were evaluated. $W k$ was calculated as follow:

$$
W k=\frac{F 0.3-F 0}{F 2-F 0}
$$

where $F_{0.3}$ and $F_{2}$ represent the fluorescence measured at 0.3 and $2 \mathrm{~ms}$, respectively, and $F_{0}$ is the basal fluorescence (Strasser et al. 2000; Stirbet et al. 2018; Lazár et al. 1999).

\subsubsection{Rapid Light Curves}

RLCs were recorded using a fluorimeter Pam2500 (Waltz, Germany). The measurements consisted of nine levels of actinic illumination with increasing intensities from 5 to $2,018 \mu \mathrm{mol} \mathrm{m}^{-2} . \mathrm{s}^{-1}$ and a duration of $30 \mathrm{~s}$. The illumination periods were separated by a 1-s saturating flash with an intensity of $14,038 \mu \mathrm{mol} \mathrm{m} \mathrm{m}^{-2} \cdot \mathrm{s}^{-1}$. RLCs for the electron transport rate (ETR), non-photochemical quenching $(N P Q)$, and the effective quantum yield $\left(\phi_{P S I I}\right)$ were measured. All curves were quantified as the sum of the individual points of the curve.

\subsubsection{PSII sensitivity to heat stress simulation}

The measurements were conducted at room temperature $\left(25^{\circ} \mathrm{C}\right)$ and stressing temperature $\left(48^{\circ} \mathrm{C}\right)$. The temperature of $48^{\circ} \mathrm{C}$ was chosen as a threshold temperature in which the changes of PSII photochemistry certainly occur (Konôpková et al. 2018; Kurjak et al. 2019), and it is still lower than $50{ }^{\circ} \mathrm{C}$, which can affect the results because of depigmentation and overall disorganization of PSII (Yamane et al. 1997).

Heat stress was simulated using a WNE22 water bath (Memmert, Germany). The shoot was enclosed in a glass Erlenmeyer flask and exposed to a temperature of $48^{\circ} \mathrm{C}$ for $30 \mathrm{~min}$ by immersing the flask in a water bath. All measurements were repeated twice per individual and the values were averaged. The severity of heat stress was calculated for each determined parameter as the ratio between the value measured at $48{ }^{\circ} \mathrm{C}$ and the control value measured at room temperature $\left(R_{F v / F m}, R_{P I}, R_{R C / A B S}\right.$, $R_{E T R}, R_{N P Q}, R_{\phi P S I I}, R_{F O}$, and $\left.R_{W K}\right)$.

\subsection{Data analysis}

Mean of 10 trees on each plot was used for further dendrometric analysis. The raw dendrometer data were used to construct a "growth line," which represents the tree stem volume under fully hydrated conditions (Oberhuber et al. 2015). The growth line connects the maximum daily value with the next equal or bigger value. During the increment phases, the growth line followed the slope of the original dendrometer records. Tree water deficit 
$(\Delta W, \mathrm{~mm})$ was determined as a difference in stem size relative to the fully hydrated conditions $(\Delta W=0)$.

Identification of significant periodicities in the seasonal course of stem circumference variation, ranging from hours to weeks, was performed by wavelet analysis (Percival \& Walden 2000; Torrence \& Compo 1998). We used the WaveletComp R package (Rösch \& Schmidbauer 2018) for the Morlet transformation, allowing a distinction between random and periodic fluctuations. The Morlet analysis in our study was based on average stem circumference variation per species. The output was a time scale plot, where the $\mathrm{x}$ - and $\mathrm{y}$-axes represent the position along the time and periodicity scales, respectively, and the color contour at each $\mathrm{x} / \mathrm{y}$ point represents the magnitude of the wavelet coefficient at that point. To detrend the stem circumference variation for growth, we used the Weibull function. Detrended data were used in the Morlet analysis where the lower period was set to 20 -min intervals, while the upper to 28 days. To explore the influence of climatic variables, data were detrended according to Oberhuber et al. (2020) using fast Furrier transform low pass filter (further termed daily detrended stem circumference variation, DDSCV). We used Pearson correlation statistics to estimate relationship among DDSCV and environmental variables of living and dead trees.

Variability of the mineral nutrition data among the forest spruce stands was tested by one-way analysis of variance (ANOVA). The data of the photosynthetic pigments and Chl a fluorescence were tested by two-way ANOVA with the factors of the seasonal period and the forest spruce stand. Subsequently, the differences were tested by the post-hoc HSD Tukey's test. Prior to the test, the normality of the data distribution was tested by the Shapiro-Wilk test. The estimated parameters were separated into two groups, namely, mineral nutrition and parameters directly related to the photosynthesis performance. These were subjected to principal component analysis (PCA) to identify the general trends of the multi-dimensional data sets. The statistical analyses were performed using the Statistica 7 program (StatSoft, Tulsa) and the R 3.6.3 software (R Core Team, Austria).

\section{Results}

\subsection{Variation in stem circumference}

The peaks in dendrometer data occurred in mid-July on all study sites (Fig. 2A). Rapid decline of derived $\Delta W$ coincided with these peaks. No changes occurred in dead tree records (Fig. 2C). The observed increase in the negative values of $\Delta W$ due to dehydration of the storage pools indicates increasing tree water deficit. Water deficit derived from band dendrometer records was lowest in the U-stand during the study period, followed by the $\mathrm{M}-$-stand and then the D-stand. The results can be divided into two separate periods: The first lasting from the beginning of May until mid-July with only a slight water deficit, and the second from mid-July until the beginning of September with a more pronounced water deficit. In the second period, the water deficit in the Dand $\mathrm{M}$-stands was roughly twice that measured in the U-stand.

SWP values on the M and $U$ sites was close to zero during the entire study period indicating favourable soil moisture condition (Fig. 2D). The correlation between SWP and $\Delta W$ was very low 0.23 on the $\mathrm{M}$ and 0.02 on the $\mathrm{U}$ site. On the lowest D site, the correlation was notably higher (0.80). The course of water deficit was synchronous on all study sites with pronounced peak in mid-July. DDSCV data showed weak and non-significant correlations to climatic variables. The exception was RH on the plot $\mathrm{D}(\mathrm{r}=0.27)$ and GR on dead tree on the $\mathrm{U}$ plot $(\mathrm{r}=$ 0.18 ). Correlation of DDSCV values among study plots was high $(r>0.9)$, contrary to negative correlations with dead tree $(\mathrm{r}<-0.45)$. When comparing the DDSTCVs of living and dead trees we observed remarkably lower amplitude in dead tree reaching less than $10 \%$ of living ones.

When inspecting the Morlet wavelet power spectra (Fig. 2B), we found a few significant periodicities in the region from 16 to 32 hours. These daily periodicities are of particular interest, reflecting the presence of increased diurnal variations, leading to the typical behavior of drought-exposed trees when the swelling phase was not able to compensate the daily shrinkage, which led to more long-term contractions.

\subsection{Needle chemical composition}

The concentrations of the individual elements are provided in Table 2, in which they were also evaluated and compared to the values arithmetical mean for spruce foliage under European conditions and the limit values of the optimal nutrition for spruce trees (Linder et al. 1995; Vrana et al. 1997; Stefan et al. 1997; Szaro et al. 2002; Maňkovská et al. 2002; Quesnel et al. 2006).

The contents of $\mathrm{N}\left(12,400-14,000 \mathrm{mg} \cdot \mathrm{kg}^{-1}\right), \mathrm{P}$ (1,100-1,200 mg.kg $\left.{ }^{-1}\right)$, and K (4,000-4,600 mg. $\left.\mathrm{kg}^{-1}\right)$ did not differ among the spruce stands along the transect (Table 2). Although the N/P concentration ratios (10.3311.6) did not decrease below 10 , indicating that phosphorus was the growth-restricting element, the contents of these elements (mainly potassium) are still under the limit of optimal nutrition for spruce stands (i.e., $\mathrm{N}$ : 14,000-18,000; P: 2,000; and K: 9,000). Also, the ratios of K/N (D-stand:32.7\%; M-stand:32.3\%; and U-stand: 36.2\%) and P/N (D-stand: 8.7\%; M-stand: 9.7\%; and U-stand: $8.5 \%$ ) are below the optimal values, i.e., $50 \%$ and $14 \%-15 \%$, respectively.

Regarding the concentrations of $\mathrm{Ca}$ and $\mathrm{Mg}$ in the needles, these were found to be lower in the D-stand much $\left(3,900\right.$ and $590 \mathrm{mg} \cdot \mathrm{kg}^{-1}$, respectively) than the 


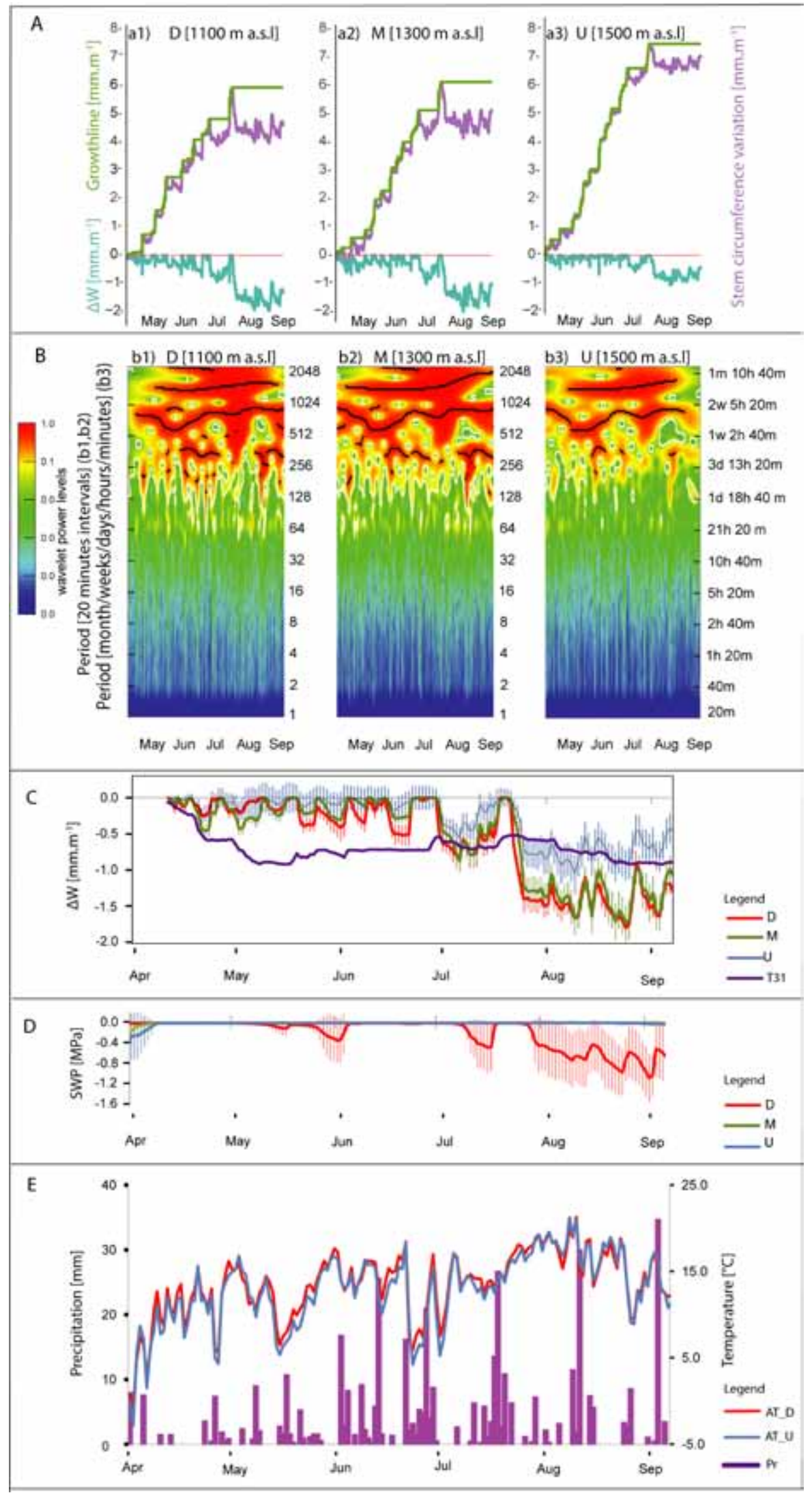

Fig. 2. Stem circumference variation with its relations for three spruce stands: A) growth-line, water deficit $(\Delta \mathrm{W})$ and stem circumference variation; B) Morlet wavelet power spectra; C) morning water deficit with confidence intervals for D-, M-, Ustands and dead tree; D) course of soil water potential on D-, M-, U-stands; E) precipitation on D-stand and air temperature on D- and U-stands. 
Table 2. Concentration of the elements in 1-year-old needles of Picea abies L. Arithmetical means (mg.kg $\left.{ }^{-1}\right)$ with their standard deviations. Different letters indicate statistically significant differences among spruce stands. Values in bold face are exceeded $(+)$ or significantly lowered $(-)$ than the arithmetical mean for spruce foliage under European conditions. *-limit value for risk elements.

\begin{tabular}{|c|c|c|c|c|c|c|c|}
\hline Element & \multicolumn{2}{|l|}{ D-stand (1,100 $\mathrm{m}$ a.s.l. $)$} & \multicolumn{2}{|c|}{ M-stand $(1,300 \mathrm{~m}$ a.s.l. $)$} & \multicolumn{2}{|c|}{ U-stand (1,500 $\mathrm{m}$ a.s.l.) } & European arithmetical mean \\
\hline $\mathrm{N}$ & $13,950 \pm 1.436^{\mathrm{a}}$ & & $12,389 \pm 1,321^{a}$ & & $12,461 \pm 2,144^{\mathrm{a}}$ & & 13,900 \\
\hline $\mathrm{P}$ & $1,218 \pm 125.8^{a}$ & - & $1,207 \pm 135.9^{\mathrm{a}}$ & - & $1,061 \pm 223.0^{\mathrm{a}}$ & - & 1,500 \\
\hline K & $4,558 \pm 599.7^{\mathrm{a}}$ & - & $4,001 \pm 334.3^{\mathrm{a}}$ & - & $4,505 \pm 904.6^{\mathrm{a}}$ & - & 6,700 \\
\hline $\mathrm{Ca}$ & $3,927 \pm 1,326^{a}$ & - & $5,325 \pm 1,567^{a b}$ & & $5,952 \pm 2,003^{b}$ & & 5,000 \\
\hline $\mathrm{Mg}$ & $594 \pm 230.2^{\mathrm{a}}$ & - & $941 \pm 300.1^{\mathrm{b}}$ & - & $714 \pm 158.8^{b}$ & - & 1,200 \\
\hline $\mathrm{Zn}$ & $15.1 \pm 5.9^{\mathrm{a}}$ & - & $21.6 \pm 10.9^{\mathrm{a}}$ & - & $22.7 \pm 6.4^{\mathrm{a}}$ & - & 45 \\
\hline $\mathrm{Fe}$ & $74.4 \pm 8.2^{\mathrm{a}}$ & & $70.0 \pm 13.6^{\mathrm{a}}$ & & $64.7 \pm 16.9^{\mathrm{a}}$ & & $50-150$ \\
\hline $\mathrm{Mn}$ & $312.5 \pm 108.9^{\mathrm{a}}$ & & $641.7 \pm 173.0^{\mathrm{b}}$ & + & $1,115 \pm 430.8^{c}$ & + & 500 \\
\hline B & $23.0 \pm 6.1^{\mathrm{a}}$ & & $29.3 \pm 5.8^{\mathrm{b}}$ & & $20.7 \pm 3.9^{\mathrm{a}}$ & & 22 \\
\hline $\mathrm{Cu}$ & $3.8 \pm 0.5^{b}$ & & $3.0 \pm 0.3^{\mathrm{a}}$ & & $3.3 \pm 0.7^{\mathrm{ab}}$ & & $3-4$ \\
\hline $\mathrm{Na}$ & $28.6 \pm 2.7^{\mathrm{a}}$ & & $27.8 \pm 2.6^{\mathrm{a}}$ & & $24.7 \pm 4.8^{\mathrm{a}}$ & & $<100^{*}$ \\
\hline $\mathrm{Al}$ & $198.4 \pm 31.5^{\mathrm{b}}$ & + & $118.5 \pm 27.7^{\mathrm{a}}$ & + & $112.0 \pm 23.5^{\mathrm{a}}$ & + & $<100^{*}$ \\
\hline
\end{tabular}

values for the optimal nutrition of spruce, i.e., 6,000 and $1,200 \mathrm{mg} \cdot \mathrm{kg}^{-1}$, respectively. Similarly, the content of $\mathrm{Mg}$ in the $\mathrm{M}-$ stand $\left(940 \mathrm{mg} \cdot \mathrm{kg}^{-1}\right.$ ) and the $\mathrm{U}-$ stand (714 mg. $\mathrm{kg}^{-1}$ ) was lower compared to the optimal values. However, the content of Ca was quite optimal, namely, $5,950 \mathrm{mg} \cdot \mathrm{kg}^{-1}$ in the U-stand and 5,330 mg. $\mathrm{kg}^{-1}$ in the M-stand.

The $\mathrm{Zn}$ concentrations only reached about $15.1 \mathrm{mg} . \mathrm{kg}^{-1}$ in the D-stand and $22.7 \mathrm{mg} . \mathrm{kg}^{-1}$ in the Ustand (Table 2). The optimal concentrations for spruce needles are reported to be in the range of $40-60 \mathrm{mg} \cdot \mathrm{kg}^{-1}$. The concentrations of Fe (64.72-74.38 mg. $\left.\mathrm{kg}^{-1}\right)$ were found to be similar to the average level for growing spruce in Europe (50-150 mg. $\mathrm{kg}^{-1}$ ). Meanwhile, the Mn concentrations were found to be on par with the European spruce average (500 mg. $\left.\mathrm{kg}^{-1}\right)$ only in the $\mathrm{M}$-stand (642 mg. $\left.\mathrm{kg}^{-1}\right)$. In the D-stand, the value was below average (313 mg. $\left.\mathrm{kg}^{-1}\right)$, and on the contrary, it was above average in the $\mathrm{U}_{-}$stand $\left(1,115 \mathrm{mg} \cdot \mathrm{kg}^{-1}\right)$. The Fe/Mn ratios found in all of the spruce stands indicate rather disproportionate amounts of these two elements, since the ratio should be $1: 2$.
The content of B can be assessed as satisfactory in all spruce stands (21-29 mg. $\mathrm{kg}^{-1}$ ), with the highest concentration found in the $\mathrm{M}$-stand. The value of $\mathrm{Cu}$ in all three spruce stands was found to be optimal within $3 \mathrm{mg} \cdot \mathrm{kg}^{-1}$. The sodium concentration (24.66-28.59 mg. $\mathrm{kg}^{-1}$ ) in these forest stands was found to be lower than optimal of average value for growing spruce in Europe (30$100 \mathrm{mg} \cdot \mathrm{kg}^{-1}$ ) (Table 2).

As the allowable limit of $\mathrm{Al}$ in the foliage of forest tree species is $100 \mathrm{mg} \cdot \mathrm{kg}^{-1}$, it was very excessive in the D-stand (198.4 mg. $\mathrm{kg}^{-1}$ ) (Table 2). Also, in the M-and U-stands, the concentrations were slightly higher (119 and $112 \mathrm{mg} . \mathrm{kg}^{-1}$, respectively).

The state of the mineral nutrition in the needles of $P$. abies was also analyzed using PCA (Fig. 3). The main nutritional elements $-\mathrm{N}, \mathrm{P}$, and $\mathrm{K}$ - formed one group, which is not correlated with either the $\mathrm{Zn}, \mathrm{Mg}$, $\mathrm{Mn}$, and Ca group or $\mathrm{Al}$. The $\mathrm{N}, \mathrm{P}$, and $\mathrm{K}$ group is almost perpendicular to the clusters formed around the average values (i.e., the central point in the figure), hence there should be no statistically significant differences between these groups of variables in the studied stands. The same

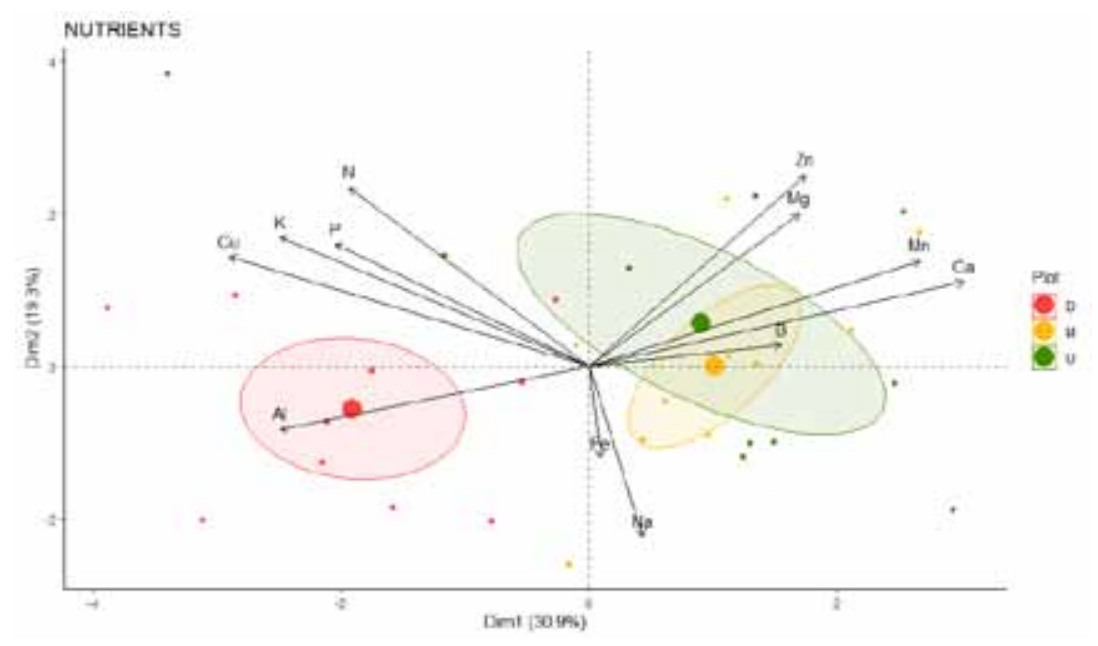

Fig. 3. The principal component analyses showing relationships of nutritional elements to the studied spruce stands. The ellipse represents $95 \%$ confidence intervals around the centroid (bigger symbol) of each data cluster. The lowest D-stand of $1,100 \mathrm{~m}$ a.s.l. is presented by red cluster, the middle $\mathrm{M}$-stand of $1,300 \mathrm{~m}$ a.s.l. by yellow cluster and the highest $\mathrm{U}-$ stand of $1,500 \mathrm{~m}$ a.s.l. by green cluster. 
could be stated for $\mathrm{Fe}$ and $\mathrm{Na}$. These independent relationships were confirmed by insignificant differences in the ANOVAs for above-mentioned elements (Table 2). Moreover, the M-stand especially follows the line of boron, and we can see a strong affinity of the D-stand to non-essential aluminum.

\subsection{Photosynthetic pigment contents and ratios}

The analysis of assimilatory pigments showed lower concentrations of chlorophylls and carotenoids, especially in the M-stand (Fig. 4). The highest spring concentration of photosynthetic pigments was found in D-stand from the lowest altitude of the transect; however, the overall highest amounts of chlorophylls and total carotenoids were recorded in late summer at the highest located $U_{-}$ stand (Fig. 4a,b). We recorded similar values of $C h l a / b$ (3.5-3.8) and low values of $\mathrm{Chl} / \mathrm{Car}$ in plot M (4.0-4.4) in late spring (Fig. 4c,d).

Interestingly, positive seasonal dynamics of chlorophyll and carotenoid contents were observed in the Ustand. Of note is also the fact that the seasonal dynamics of the photosynthetic pigments in the spruce needles in the D-stand were suppressed and the values were uniform during the vegetation season.
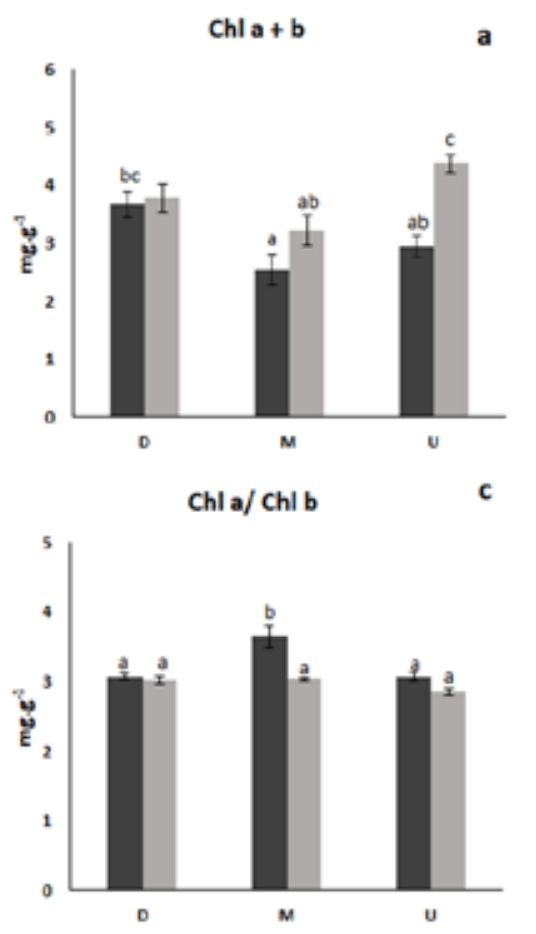

\subsection{Photosystem II performance and thermostability}

The parameters of the fast $C h l a$ fluorescence kinetics were relatively stable. No differences in $F_{v} / F_{m}$ among the plots over the whole measuring period were found; however, there were statistically significant differences between the D-stand with the lowest $F_{\mathrm{v}} / F_{\mathrm{m}}$, ratio $(0.800)$ in August and the U-stand with the highest one (0.834) in June (Fig. 5). $R C / A B S$ and $P I$ were similar for all forest stands in June, as well as in August.

The measurements of the slow Chl a fluorescence kinetics were found to be more sensitive toward stress. The highest $\phi_{P S I I}$ and, consequently, the highest ETR and the lowest $N P Q$ were found in the U-stand in the spring (Fig. 6). Moreover, in the U-stand, seasonal dynamics were observed, with a significant decrease in the ETR and $\phi_{P S I I}$ parameters during the late summer.

We simulated heat stress (up to $48^{\circ} \mathrm{C}$ ) in order to reveal differences in the response of PSII to increased temperature. The values of $R_{F v / F m}$ were slightly lower for samples measured in June compared to August, but no statistically significant differences between the months or stands were confirmed (Fig. 7). The ratios of $R_{P I}, R_{R C /}$ ${ }_{A B S}, R_{E T R}$, and $R_{N P Q}$ decreased to below 1 , indicating a higher level of stress. These values were the lowest in the spring samples from the D-stand, and the highest in the late summer samples from the U-stand. On the contrary,
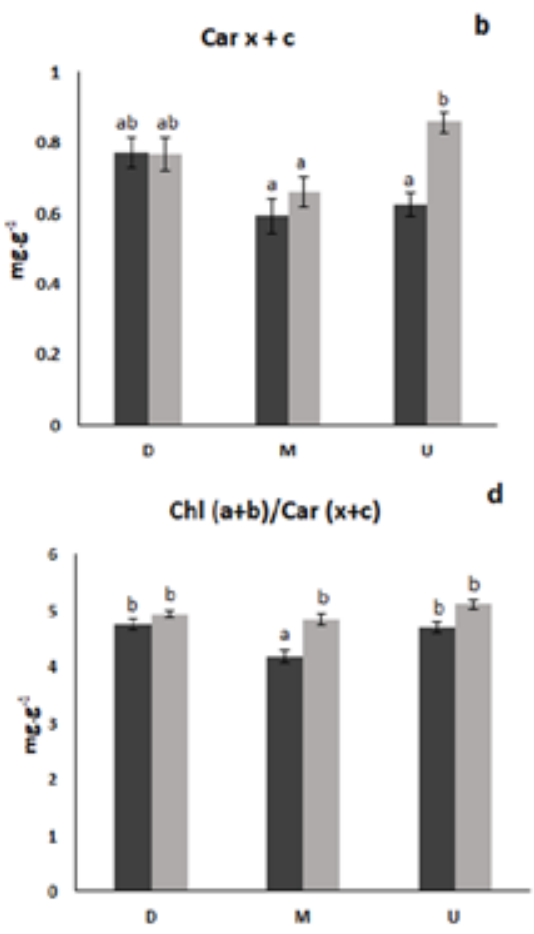

Fig. 4. Concentrations (mg. $\mathrm{g}^{-1}$ ) of a) $a+b$ chlorophylls, b) $x+c$ carotenoids and their ratios: c) $a / b$, d) $C h l(a+b) / C a r(x+c)$ in spruce needles on the studied stands. The graph's bars with spruce stand's means and standard errors. Different letters indicate statistically significant differences among groups. Season is identified by different colors: the beginning of June (late spring) dark grey color, the end of August (late summer) - light grey color. 

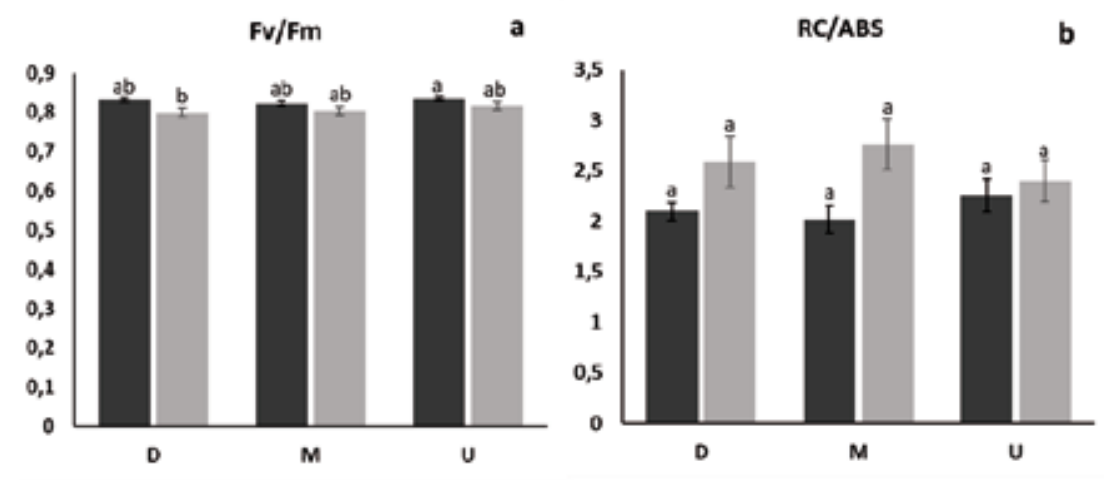

PI

c

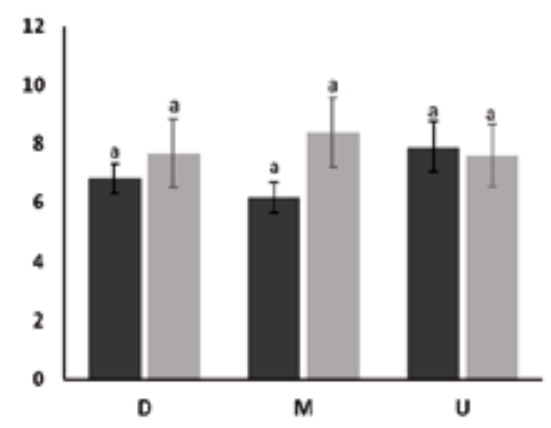

Fig. 5. Parameters of fast kinetics of chlorophyll a fluorescence: a) $F_{v} / F_{\mathrm{m}}$, b) $R C / A B S$, c) $P I$. The graph's bars present spruce stand's mean (relative unit) with standard errors. Different letters indicate statistically significant differences among groups. Season is identified by different colors: the beginning of June (late spring) - dark grey color, the end of August (late summer) light grey color.
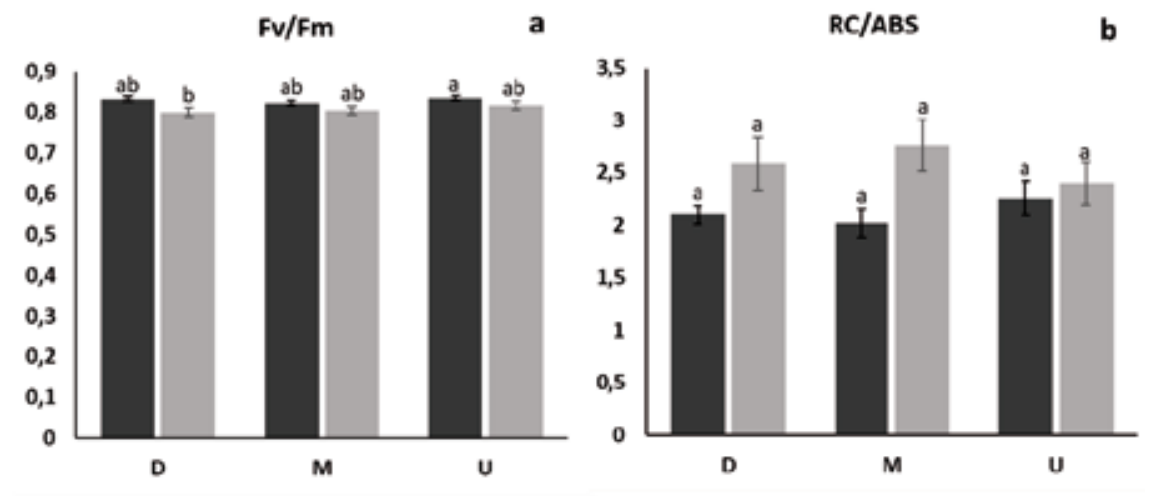

PI

c

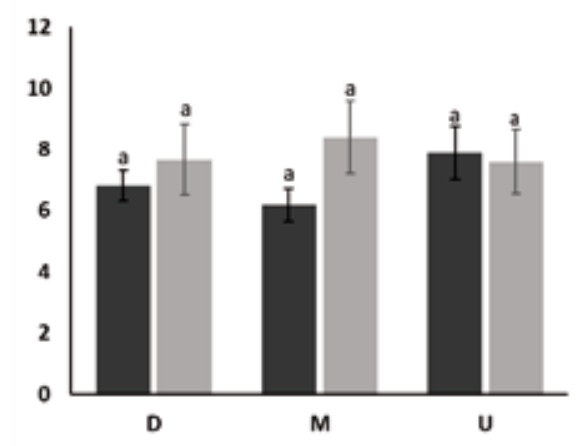

Fig. 6. Fluorescence parameters of Rapid Light Curves (RLCs): a) $\phi_{P S I P}$ b) ETR, c) $N P Q$. The graph's bars present spruce stand's mean (relative unit) with standard errors. Different letters indicate statistically significant differences among groups. Season is identified by different colors: the beginning of June (late spring) - dark grey color, the end of August (late summer) - light grey color. 

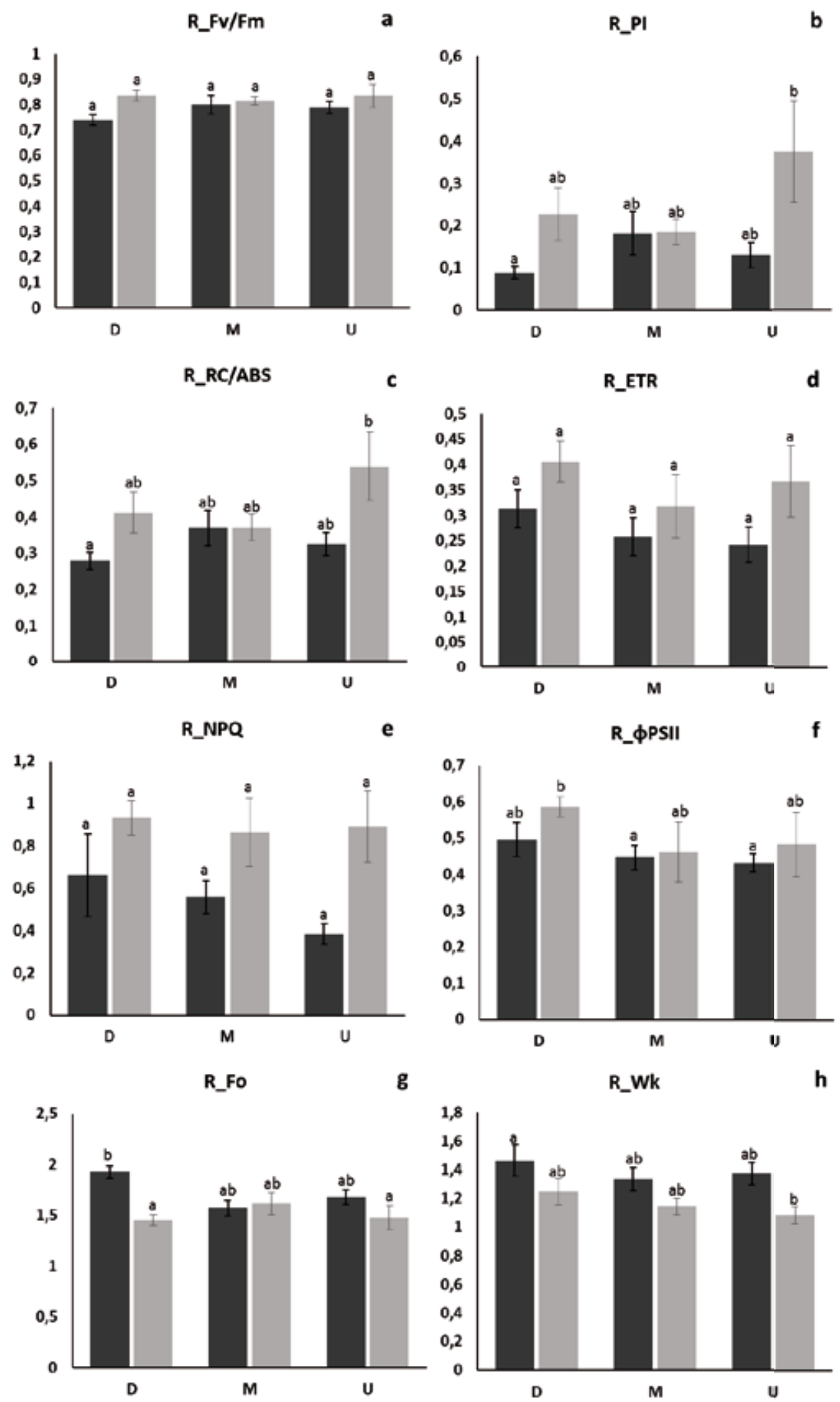

Fig. 7. The ratios of fluorescence parameters after heat stress simulation (the value measured at $48^{\circ} \mathrm{C}$ ) and before stress simulation (control value measured at room temperature $24^{\circ} \mathrm{C}$ ): a) $R_{F V / F m}$, b) $R_{P I}$, c) $R_{R C / A B S}$, d) $R_{E T R}$, e) $R_{N P O}$, f) $R_{\phi P S I I}$, g) $R_{F V}$, h) $R_{W k}$. The graph's bars present spruce stand's mean (relative unit) with standard errors. Different letters indicate statistically significant differences among groups. Season is identified by different colors: the beginning of June (late spring) - dark grey color, the end of August (late summer) - light grey color. 
the values $R_{W k}$ and $R_{F 0}$ describe opposite behaviour compared to previously mentioned parameters. Therefore, as expected, the lowest values of $R_{W k}$ were detected in the U-stand and the highest in the D-stand. Noteworthy, the highest $R_{F O}$ was found in the D-stand in June, and also the lowest $R_{F O}$ with the highest $\phi_{P S I I}$ was found in the same stand in August.

Based on the PCA, we captured the seasonal variability of PSII performance. In June, there were remarkable differences among the forest stands along the Lomnicky peak transect (Fig. 8). The D-stand (lowest) followed mainly chlorophylls, carotenoids, $R_{E T R}$, and $R_{\phi P S I I}$ after heat simulation, but also NPQ before and after heat simulation. Meanwhile, the M-stand (middle) followed mainly $R_{R C / A B S}$ and $R_{P I}$ after heat stress, and the U-stand (highest) showed significant ETR and $\phi_{P S I}$. The parameters of $F v / F m, R C / A B S, P I$, and $R_{W k}$ stayed uniform, without clear inclination toward a certain forest stand. In the late summer, the forest stands were more overlapped and showed more uniform functioning (Fig. 9). The significance of the assimilatory pigment content for the D-stand weakened, while the performance of the photosystems under normal conditions stayed, more or less, constant among stands, with only post-heat stress differences being slightly noticeable. The significance of $R_{F 0}$ and $R_{W k}$ increased for the D- and M-stands; hence, the significance of $R_{P I}$ and $R_{R C / A B S}$ increased for the Ustand.

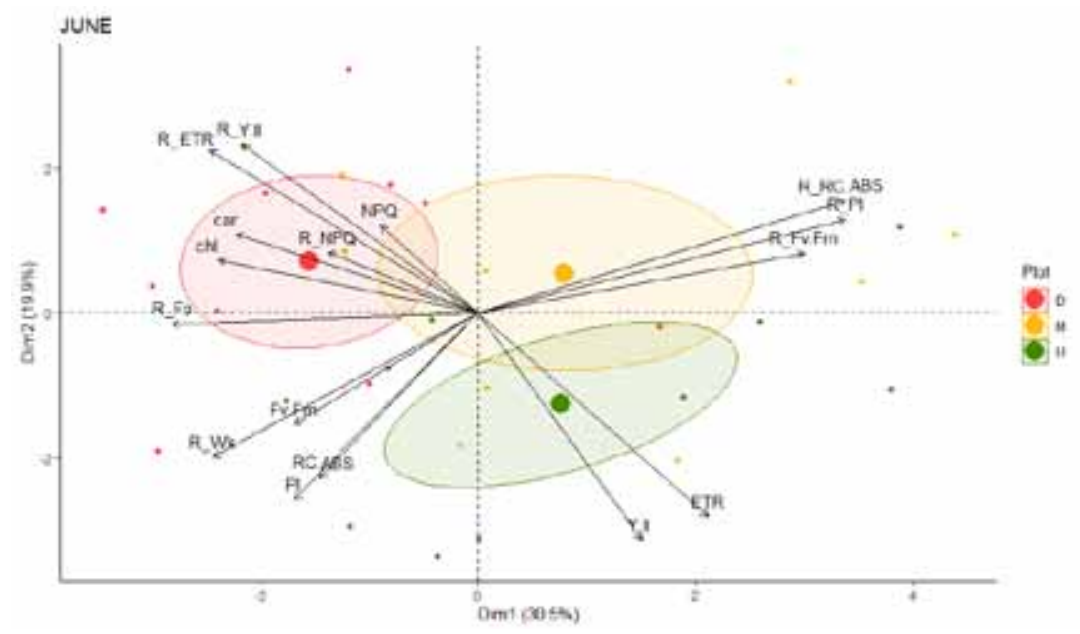

Fig. 8. The principal component analyses showing relationships of chlorophyll pigments and chlorophyll $a$ fluorescence parameters to the studied spruce stands at the beginning of June (late spring). The ellipse represents $95 \%$ confidence intervals around the centroid (bigger symbol) of each data cluster. The lowest D-stand of 1,100 $\mathrm{m}$ a.s.l. is presented by red cluster, the middle $\mathrm{M}$-stand of 1,300 $\mathrm{m}$ a.s.l. by yellow cluster and the highest $\mathrm{U}$-stand of $1,500 \mathrm{~m}$ a.s.l. by green cluster.

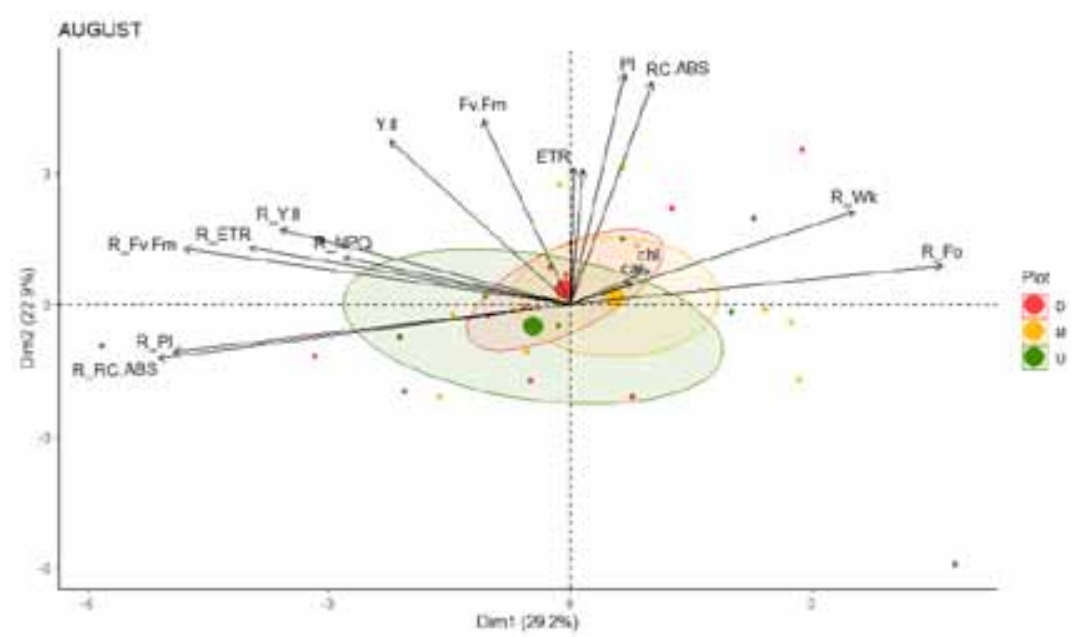

Fig. 9. The principal component analyses showing relationships of chlorophyll pigments and chlorophyll $a$ fluorescence parameters to the studied spruce stands at the end of August (late summer). The ellipse represents $95 \%$ confidence intervals around the centroid (bigger symbol) of each data cluster. The lowest D-stand of 1,100 m a.s.l. is presented by red cluster, the middle $\mathrm{M}-$ stand of $1,300 \mathrm{~m}$ a.s.l. by yellow cluster and the highest $\mathrm{U}-$ stand of $1,500 \mathrm{~m}$ a.s.l. by green cluster. 


\section{Discussion}

The course of the stem circumference variations and the derived growth lines at 1,100 and 1300 ma.s.lwere almost identical. In both cases, water deficit was relatively low, indicating favorable hydric conditions, despite the occurrence of short drought periods $(\Delta \mathrm{W}<0)$ (Fig. 2). Complete rehydration occurred until mid-July, when stem circumference size culminated. Since then, pronounced drought conditions occurred ( $\Delta W$ ranged from -1.5 up to $-2.0 \mathrm{~mm} \cdot \mathrm{m}^{-1}$ ). The hydric conditions in the upper site differed notably as the rehydration remained continuous. However, water deficit occurred at the same time as in the lower sites, but to a smaller magnitude $(-0.5$ up to $-1.0 \mathrm{~mm} . \mathrm{m}^{-1}$ ). Based on the results of Ježík et al. (2015), we may estimate the presence of increased drought stress when $\Delta W$ falls below $-1.0 \mathrm{~mm} \cdot \mathrm{m}^{-1}$ in young spruce stands, while based on that of Nalevanková et al. (2018), it seems that the values signalizing increased and more pronounced drought were approximately three times lower (absolute deviation from zero values) for mature beech stands.

We interpret the peaks in dendrometer records as representation of stem water status rather than stem reaction to surrounding atmosphere conditions. This is in contrast with Oberhuber et al. (2020) who found highly synchronous course (amplitude and frequency) of DDSTCV on both living and dead trees. He attributed it to hygroscopic swelling and shrinkage of the outer bark tissues. In our study the DDSTCV of dead tree showed only partial amplitude of living trees (less than 10\%). We understand this fact because of continuously water saturated bark tissue under moist mountain conditions. Low correlations among DSTCV and environmental variables on different plots and on dead tree supports the statement on water saturated bark tissue conditions. Thus, we interpret the peaks in dendrometer data as phenophysiological process which needs to be further investigated. Despite favourable SWP and weather condition even on the most humid U site water deficit was present. We attribute this reaction to sensitivity of spruce to the irregularities in precipitation (Fig. 2E) which might not influence SWP.

The Morlet spectra revealed almost identical patterns of periodical change in stem circumference on a diurnal scale (58-80 20-min intervals), confirming the same water status and response in the D-and M-stands. Similar periodic events also occurred in lower frequencies (i.e., several days). The Morlet analysis of the U-stand showed less pronounced daily periodicity, indicating less effort to balance the tree and environment water requirements. Low-frequency periodicity was also less evident than in previous stands, especially from mid-July.

The majority of the detected elements in the spruce foliage showed values below the average concentrations for first-year needles, as documented for Carpathian spruce forests (Linder et al. 1995; Bublinec 1994;
Maňkovská et al. 2002) and also Canadian boreal spruce forests (Quesnell et al. 2006). Our results show that these spruce stands (growing mainly on podzols and rankers), located in high mountainous regions, do have not optimal mineral nutrition. The geographical extension of Norway spruce is primarily located in nutrient-poor, infertile environments, and spruce typically grows under acidic soil conditions with a thick organic layer (Schmidt-Vogt 1991; Baier et al. 2006). Boreal and temperate spruce forest stands have a naturally low availability of nitrogen $(\mathrm{N})$, which is often the primary growth-limiting nutrient in these soils (Tamm 1991; Binkley \& Fisher 2013). Nowadays, there are increased polemics if the fertilization enhances the vitality and growth of poor spruce stands (Bergh et al. 2014), and also if it is suitable as a measure to sequester more carbon (C) (Gundale et al. 2014). The increased biomass growth, after supplying a growth-limiting nutrient, tends to dilute other nutrients (Koricheva et al. 1998; George \& Seith 1998), and decreases the tolerance of trees against soil-borne (e.g., deficiency of other mineral nutrients) stress factors. Also, nitrogen deposition has been shown to have a positive effect on herbivorous insect populations (Throop \& Lerdau 2004; Strengbom et al. 2005). Another meta-analysis showed that species adapted to resource-rich habitats grow inherently faster and invest less in defences than species adapted to less-productive habitats (Endara \& Coley 2011; Nybakken 2018).

Regarding $\mathrm{Ca}$ and $\mathrm{Mg}$, which are common enzymatic activators in metabolic physiological processes, optimal concentrations were found only in case of $\mathrm{Ca}$ in the upper $\mathrm{M}$ - and U-stands. Especially a shortage of magnesium, as a core component of chlorophylls, may lead to damage of the processes in chlorophyll synthesis, which is then reflected in a reduction of chlorophyll content and premature needle yellowing. Since the equilibrium of individual elements in trees is a precondition of their vitality and normal growth (Markert 2003), the ratios of $\mathrm{Ca} / \mathrm{Mg}$ were limited (3.7-8; Maňkovská et al. 2002) in all three stands, and the $\mathrm{Ca} / \mathrm{N}$ ratios were optimal only in the $\mathrm{M}-$ and U-stands.

Synergic and antagonistic relationships between individual elements can be disturbed by different stress factors (Markert 2003). We recorded relatively high amounts of $\mathrm{Mn}$ in the upper U-stand. Although Mn mobilization may indicate the disturbance of the equilibrium in spruce physiology, leading to disproportionate levels of iron, which was also confirmed in our case, this phenomenon is quite common, since a few studies have confirmed that the highest mobilization of manganese appeared in higher altitudes (Kaupenjohan et al. 1989; Maňkovská et al. 2002). On the other hand, an enormously high aluminum content recorded in the lower D-stand can have a much greater negative effect on the balance of the physiological processes. Based on the decreases in exchangeable base cations $\left(\mathrm{Ca}^{2+}\right.$ and $\mathrm{Mg}^{2+}$ ) and the increases in exchangeable $\mathrm{Al}$ in the spruce 
needles of this stand, we can presume soil acidification occurred. For the entire Carpathian Mountains range, the highest concentrations of Al were determined for spruce in Poland: $140 \mathrm{mg} \cdot \mathrm{kg}^{-1}$ (Maňkovská et al. 2002). The Al concentrations detected in the $\mathrm{D}$-stand were even higher than this value. We expect that in this case, aluminum is deposited mainly in the form of precipitation from more distant polluted areas, and may be leached from higher to lower stands.

Moreover, stress factors negatively affected the state of the photosynthetic pigments of the spruce forests along the Lomnicky peak transect, mainly in the M-stand. Ditmarová et al. (2007b) found that the values of total chlorophyll pigments during the vegetation season in the healthy trees of natural spruce stands in the Zadná Polana National Nature Reserve (Slovakia) were in the range of 3.26-4.81 mg. $\mathrm{g}^{-1}$. The average concentrations in our study were $2.53-4.37 \mathrm{mg} . \mathrm{g}^{-1}$. The values of the $\mathrm{Chl} /$ Car ratio (3-5) revealed the weakened photo-protective function of the photosynthetic apparatus of all evaluated stands. Although the percentage of defoliation was quite high in the D- and M-stands, the assimilatory organs were not seriously damaged with regard to the photosynthetic pigment ratios, because the values did not decrease to below 3 (Lichtenthaler 1987). Additionally, the findings of the maximal pigment concentration during late summer in the U-stand may provide useful insight into the seasonal dynamics of pigment concentrations. Similar results were found by Kmetet al. (2010) with a natural seasonal course for undamaged spruce trees and without such dynamics for damaged trees with yellowing symptoms. Based on our results, we can presume that forest stands with a seasonal increase in chlorophyll pigment concentration are more vital than stands without seasonal improvement.

The parameters of the fast and slow Chl a fluorescence measured in all spruce stands did not indicate reduced capacity of the primary photosynthetic processes during the vegetation season. The values of one of the basic parameters, namely, $F_{v} / F_{m}$, for the whole sample set in June and August were recorded as favorable, not dropping close to the disturbance limit (0.725) (Critchley 2000). Measurements before and after the occurrence of high temperatures allowed us to evaluate changes in the performance of PSII; indeed, the Chl a fluorescence parameters have been recognized as excellent indicators of high temperature stress in PSII (Brestic \& Zivcak 2013; Mathur et al. 2014; Kalaji et al. 2017). The photosynthetic performance of PSII evaluated by fluorescence traits was higher at the beginning of June. Nevertheless, the thermostability of PSII during June was lower in comparison to that in August. Simulation of heat stress led to a decrease in the efficiency of the primary photochemistry in PSII. The most negatively influenced were the fluorescence parameters in the D-stand. The photosynthetic performance index $\left(R_{P I}\right)$, as well as the density of active reactions centers $\left(R_{R C / A B S}\right)$, significantly reduced and the values of $\mathrm{K}$-step ( $W k$ ) and the basal fluorescence $\left(F_{0}\right)$ increased. This was expected, as increasing of the variable fluorescence in the $\mathrm{K}$-step has previously been observed, especially under thermal stress and high levels of $F_{0}$ and $W k$, indicating serious damages to the PSII (Strasser et al. 2000).

After heat simulation, we also observed a high stimulation of non-photochemical quenching $(N P Q)$ in all spruce stands, due to the increase in energy dissipation as heat. Leaf temperatures above $35^{\circ} \mathrm{C}$ cause an initial decrease in the photochemical efficiency of most plants, which is accompanied by an increase in $N P Q$ in order to reduce the energy available for photochemistry and as a mechanism of plant defense against thermal stress (Müller et al. 2001; Mathur et al. 2014).

Our results also indicate that the differences in the performance of PSII among the forest stands were well detected at the beginning of June (late spring), as we can see from the PCA results. Since the fluorescence parameters are closely linked to photosynthesis, we suppose that these processes are more active during the rapid growth (i.e., in spring and at the start of summer) of spruce trees, and are also more influenced by heat stress in this period.

\section{Conclusion}

We analysed vitality status of three spruce stands affected by windstorms in 2004 and 2014, drought stress (annually from 2015), and consequently, disturbed by bark beetles. Based on our research, we can conclude that there are certain differences in the vitality of these spruce stands, which were recorded by using an eco-physiological assessment/approach. The lowest spruce stand, i.e., the D-stand at 1,100 $\mathrm{m}$ a.s.l., displayed the lowest concentrations of the basic nutrition cations and high $\mathrm{Al}$ concentrations in the needles, the most affected performance of the PSII after heat stress simulation, and no seasonal dynamics of photosynthetic pigments. The best physiological vitality was detected in the highest spruce stand at $1,500 \mathrm{~m}$ a.s.l. However, as shown in this study, using heat stress simulation, future increasing temperatures and drought periods may lead to the rapid disintegration of these spruce forest stands, which are already seriously weakened by Ips typographus. Photosynthesis, as the most sensitive physiological process, might be negatively influenced by high temperature during periods of intensive tree growth, when the photosystems are the most active, and concurrently, the highest nutrient consumption occurs.

\section{Acknowledgement}

This study was supported by the grant of the Slovak Agency for Research and Development APVV-16-0306, APVV-18-0390, $A P V V-17-0644$ and the grant of the Slovak Grant Agency for Science VEGA 2/0049/18. 


\section{References}

Allen, C. D., Macalady, A. K., Chenchouni, H., Bachelet, D., McDowell, N., Vennetier, M. et al., 2010:A global overview of drought and heat-induced tree mortality reveals emerging climate change risks for forests. Forest Ecology and Management, 259:660-684.

Baier, R., Ettl, R., Hahn, Ch., Göttlein, A., 2006: Early development and nutrition of Norway spruce (Picea abies [L.] Karst.) seedlings on different seedbeds in the Bavarian limestone Alps - a bioassay. Annals of Forest Science, 63:339-348.

Baker, N. R., 2008: Chlorophyll fluorescence: a probe of photosynthesis in vivo. Annual Review of Plant Biology, 59:89-113.

Bergh, J., Nilsson, U., Allen, H. L., Johansson, U., Fahlvik, N., 2014: Long-term responses of Scots pine and Norway spruce stands in Sweden to repeated fertilization and thinning. Forest Ecology and Management, 320:118-128.

Binkley, D., Fisher, R. F., 2013: Ecology and Management of Forest Soils. Chichester: Wiley-Blackwell, $456 \mathrm{p}$.

Bonan, G. B., Van Cleve, K., 1992: Soil temperature, nitrogen mineralization, and carbon source-sink relationship in boreal forests. Canadian Journal of Forest Research, 22:629-639.

Brestic, M., Zivcak, M., 2013: PSII Fluorescence Techniques for Measurement of Drought and High Temperature Stress Signal in Crop Plants: Protocols and Applications. In: Rout, G. R., Das, A. B. (eds.): Molecular Stress Physiology of Plants. India, Springer India, p. 87-131.

Bublinec, E., 1994: Concentration, accumulation and cycling of elements in beech and spruce ecosystems. Bratislava, VEDA, 132 p.

Bussotti, F., Gerosa, G., Digrado, A., Pollastrini, M., 2020: Selection of chlorophyll fluorescence parameters as indicators of photosynthetic efficiency in large scale plant ecological studies. - Ecological Indicators. 108:105686.

Chen, Y., Han, W., Tang, L., Tang, Z., Fang, J., 2013: Leaf nitrogen and phosphorus concentrations of woody plants differ in responses to climate, soil and plant growth form. Ecography, 36:178-184.

Critchley, C., 2000: Photoinhibition. In: Raghavendra, A.S. (ed.): Photosynthesis - a comprehensive treatise. Cambridge University Press, p. 264-273.

Croft, H., Chen, J. M., Luo, X., Bartlett, P., Chen, B., Staebler, R. M., 2017: Leaf chlorophyll content as a proxy for leaf photosynthetic capacity. Global Change Biology, 23:3513-3524.

Ditmarová, L., Kmet', J., Ježík, M., Válka, J., 2007a: Mineral nutrition in relation to the Norway spruce forest decline in the region Horný Spiš (Northern Slovakia). Journal of Forest Science, 53:93-100.
Ditmarová, L'., Kmet', J., Střelcová, K., 2007b: Stand microclimate and physiological state of common beech (Fagus sylvatica L.) and Norway spruce (Picea abies Karst. L.) at Predná Pol'ana. In: Střelcová, K., Škvarenina, J. \& Blaženec, M. (eds.): Bioclimatology and natural hazards, International Scientific Conference, Polana nad Detvou, Slovakia, 17.-20.9.2007. Zvolen, TUZVO, $228 \mathrm{p}$.

Ehrenberger, W., Rüger, S., Fitzke, R., Vollenweider, P., Günthardt-Goerg, M., Kuster, T. et al., 2012: Concomitant dendrometer and leaf patch pressure probe measurements reveal the effect of microclimate and soil moisture on diurnal stem water and leaf turgor variations in young oak trees. Functional Plant Biology, 39:297-305.

Endara, M. J., Coley, P. D., 2011: The resource availability hypothesis revisited: a meta-analysis. Functional Ecology, 25:389-398.

Fleischer, P., Homolová, Z., 2011: Long-term ecological research in larch-spruce forest community after natural disturbances in the Tatra Mts. Forestry Journal, 57:237-250.

Fredeen, A. L., Raab, T. K., Rao, I. M., Terry, N., 1990: Effects of phosphorus nutrition on photosynthesis in Glycine max (L.) Merr. Planta, 181:399-405.

George, E., Seith, B., 1998: Long-term effects of a high nitrogen supply to soil on growth and nutritional status of young Norway spruce trees. Environmental Pollution, 102: 301-306.

Gundale, M. J., From, F., Bach, L. H., Nordin, A., 2014: Anthropogenic nitrogen deposition in boreal forests has a minor impact on the global carbon cycle. Global Change Biology, 20:276-286

Hlásny, T., Mátýás, C., Seidl, R., Kulla, L., Merganičová, K., Trombík, J. et al., 2014: Climate change increases the drought risk in Central European Forests: What are the options for adaptation? Lesnícky časopis Forestry Journal, 60:5-18.

Húdoková, H., Konôpková, A., Kurjak, D., 2017: The possibilities of using of fast kinetics of chlorophyll $a$ fluorescence for the assessment of PSII thermostability on the example of European beech. Acta Facultatis Forestalis Zvolen, 59:15-25.

Ježík, M., Blaženec, M., Letts, M. G., Ditmarová, L', Sitková, Z., Střelcová, K., 2015: Assessing seasonal drought stress response in Norway spruce (Picea abies [L.] Karst.) by monitoring stem circumference and sap flow. Ecohydrology, 8:378-386.

Jokela, A., Sarjala T., Huttunen, S., 1998: The structure and hardening status of Scots pine needles at different potassium availability levels. Trees, 12:490-498.

Jyske, T., Mäkinen, H., Kalliokoski, T., Nöjd, P., 2014: Intraannual tracheid production of Norway spruce and Scots pine across a latitudinal gradient in Finland. Agricultural and Forest Meteorology, 194:241-254. 
Kalaji, H. M., Schansker, G., Ladle, R. J., Goltsev, V., Bosa, K., Allakhverdiev, S. I. et al., 2014: Frequently asked questions about chlorophyll fluorescence: practical issues. Photosynthetic Research, 122:121-158.

Kalaji, H. M., Schansker, G., Brestic, M., Bussotti, F., Calatayud, A., Ferroni, L. et al., 2017: Frequently asked questions about chlorophyll fluorescence, the sequel. Photosynthetic Research, 132:13-66.

Kaupenjohan, M., Zech, W., Hantschel, R. Horn, R., Schneider, B. U., 1998: Mineral nutrition of forest trees. A regional survey. In: Schultze, E. D., Lange, O., L., Oren, R. (eds.): Forest decline and air pollution. Ecological studies 77, Berlin, Springer Verlag, p. 182-294.

Kmet', J., Ditmarová, L., Priwitzer, T., Kurjak, D., Baláž, P., Blaženec, M., 2010: Physiological limits - a possible cause of spruce decline. Beskydy, 3:55-64.

Konôpková, A., Kurjak, D., Kmet', J., Klumpp, R., Longauer, R., Ditmarová, L. et al., 2018: Differences in photochemistry and response to heat stress between silver fir (Abies alba Mill.) provenances. Trees, 32:73-86.

Koreň, M., 2005: Vetrová kalamita 19. novembra $2004-$ nové pohlady a konsequencie. Tatry, p. 7-29.

Koricheva, J., Larsson, S., Haukioja, E., Keinänen, M., 1998: Regulation of woody plant secondary metabolism by resource availability: hypothesis yesting by means of meta-analysis. Oikos, 83:212-226.

Kunca, A., Zúbrik, M., Galko, J., Vakula, J., Leontovyč, R., Konôpka, B. et al., 2019: Salvage felling in the Slovak Republic's forests during the last twenty years (1998-2017). Central European Forestry Journal, 65:3-11.

Kurjak, D., Konôpková, A., Kmet', J., Macková, R., Frýdl, J., Živčák, M.et al., 2019: Variation in the performance and thermostability of photosystem II in European beech (Fagus sylvatica L.) provenances is influenced more by acclimation than by adaptation. Journal of Forest Research, 138:79-92.

Lazár D., Pospíšil P., Nauš J., 1999: Decrease of fluorescence intensity after the K step in chlorophyll $a$ fluorescence induction is suppressed by electron acceptors and donors to photosystem II. Photosynthetica, 37:255-265.

Li, Y., He, N., Hou, J., Xu, L., Liu, C., Zhang, J. et al., 2018: Factors Influencing Leaf Chlorophyll Content in Natural Forests at the Biome Scale. Frontiers in Ecology and Evolution, 6:64.

Lichtenthaler, H. K., 1987: Chlorophylls and carotenoids: Pigments of photosynthetic biomembranes. Methods in enzymology, 148:350-382.

Linder, S., 1995: Foliar analysis for detecting and correcting nutrient imbalances in Norway spruce. Ecol. Bull. (Copenhagen), 44:118-190.
Lindner, M., Fitzgerald, J. B., Zimmermann, N. E., Reyer, C., Delzon, S., van der Maaten, E. et al., 2014: Climate change and European forests: what do we know, what are the uncertainties, and what are the implications for forest management? Journal of Environmental Management, 146:69-83.

Maňkovská, B., Černý, M., Moravčík, P., Godzik, B., Grodzińska, K., Badea, O. et al., 2002: In: Szaro, R. C. et al. (eds.): Effects of air pollution on forest health and biodiversity in Forests of the Carpathian Mountains. IOS Press, p. 173-184.

Markert, B., 2003: Interelement correlations detectable in plant samples based on data from reference materials and highly accurate research samples. Fresenius Journal of Analytical Chemistry, 345:318-322.

Mathur, S., Agrawal, D., Jajoo, A., 2014: Photosynthesis: Response to high temperature stress. Journal of Photochemistry and Photobiology B: Biology, 137:116-126.

Müller, P., Li, X. P., Niyogi, K. K., 2001: Non-Photochemical Quenching. A Response to Excess Light Energy. Plant Physiology, 125:1558-1566.

Nybakken, L., Lie, M. H., Julkunen-Tiitto, R., Asplund, J., Ohlson, M., 2018: Fertilization Changes Chemical Defense in Needles of Mature Norway Spruce (Picea abies). Frontiers in Plant Science, 9:770.

Oberhuber, W., Hammerle, A., Kofler, W., 2015: Tree water status and growth of saplings and mature Norway spruce (Picea abies) at a dry distribution limit. Frontiers in Plant Science, 6:1-12.

Oberhuber, W., Sehrt, M., Kitz, F., 2020: Hygroscopic properties of thin dead outer bark layers strongly influence stem diameter variations on short and long-time scales in Scots pine (Pinus sylvestris L.). Agricultural and Forest Meteorology, 290:108026.

Quesnel, P. O., Côté, B., 2009: Prevalence of Phosphorus, Potassium, and Calcium Limitations in White Spruce across Canada. Journal of Plant Nutrition, 32:1290-1305.

Percival, D. B., Walden, A. T., 2000: Wavelet Methods for Time Series Analysis. Cambridge University Press, Cambridge UK.

Rösch, A., Schmidbauer, H., 2018: WaveletComp: Computational Wavelet Analysis. R package version 1.1. https://CRAN.R-project.org/ package $=$ WaveletComp

Schmidt-Vogt, H., 1991: Die Fichte. Hamburg and Berlin, Parey, 607 p.

Schwarz, M., Moravčík, M., 2009: Rámcové plánovanie a adaptácia lesných porastov na klimatickú zmenu. Lesnícky časopis - Forestry Journal, 55:273-285.

Schütz, J., Götz, M., Schmid, W., Mandallaz, D., 2006: Vulnerability of spruce (Picea abies) and beech (Fagus sylvatica) forest stands to storms and consequences for silviculture. European Journal of Forest Research, 125:291-302. 
Spiecker, H., 2003: Silvicultural management in maintaining biodiversity and resistance of forests in Europe - temperate zone. Journal of Environmental Management, 67:55-65.

Stefan, K., Fürst, A., Hacker, R., Bartels, U., 1997: Forest foliar condition in Europe. Technical report. EC and UN/ECE, Brussels, Geneva, 191 p.

Stirbet, A., Lazár, D., Kromdijk, J., Govindjee, E., 2018: Chlorophyll a fluorescence induction: Can just a onesecond measurement be used to quantify abiotic stress responses? Photosynthetica, 56:86-104.

Strasser, R. J., Srivastava, A., Tsimilli-Michael, M., 2000: The fluorescence transient as a tool to characterize and screen photosynthetic samples. In: Yunus, M., Pathre, U., Mohanty, P. (eds.): Probing Photosynthesis: Mechanisms, Regulation and Adaptation. London, Taylor \& Francis, p. 445-483.

Strengbom, J., Witzell, J., Nordin, A., Ericson, L., 2005: Do multitrophic interactions override $\mathrm{N}$ fertilization effects on Operophtera larvae? Oecologia, 143:241250.

Szaro, R. C., Bytnerowicz, A., Oszlányi, J., 2002: Effects of air pollution on forest health and biodiversity in forests of the Carpathian Mountains. NATO Science Series, IOS Press, $303 \mathrm{p}$.

Šrámek, V., Vejpustková, M., Novotný, R., Hellebrandová, K., 2008: Yellowing of Norway spruce stands in the Silesian Beskids-damage extend and dynamics. Journal of Forest Science, 54:55-63.
Tamm, C. O., 1991: Nitrogen in Terrestrial Ecosystems. Berlin: Springer Verlag, 128 p.

Throop, H., Lerdau, M., 2004: Effects of Nitrogen Deposition on Insect Herbivory: Implications for Community and Ecosystem Processes. Ecosystems, 7:109133.

Torrence, C., Compo, G. P., 1998: A practical guide to wavelet analysis. Bulletin of the American Meteorological Society, 79:61-78.

Tužinský, L., Bublinec, E., Tužinský, M., 2017: Development of soil water regime under spruce stands. Folia Oecologica, 44:46-53.

Uniyal, S. K., Uniyal, A., 2009: Climate change and largescale degradation of spruce: Common pattern across the globe. Climate Research, 38:261-263.

Vakula, J., Zúbrik, M., Kunca, M., Dubec, M., Find'o, S., Galko, J. et al., 2015: Nové metódy ochrany lesa. Zvolen, NLC, 292 p.

Vrana, K., Rapant, S., Bodiš, D., Marsina, K., Maňkovská, B., Čurlík, J.et al., 1997: Geochemical Atlas of the Slovak Republic at a scale of $1: 1,000,000$. Journal of Chemical exploration, 60:7-37.

Zúbrik, M., Kunca, A., Csóka, G., Forster, B., Hâruta, O., Hoch, G. et al., 2013: Insects and diseases damaging trees and shrubs of Europe. N.A.P. Editions, 535 p.

Yamane, Y., Kashino, Y., Koike, H., Satoh, K., 1997: Increases in the fluorescence Fo level and reversible inhibition of Photosystem II reaction center by hightemperature treatments in higher plants. Photosynthesis Research, 52:57-64. 